\title{
ANALYSIS THE SPREAD OF CHLOROPHYLL-a CONCENTRATION IN BIRAH-BIRAHAN ISLAND WATERS USING LANDSAT 8 IMAGES
}

\author{
*Rosdianto ${ }^{1}$, Kaharuddin $^{2}$, Rudiyanto $^{3}$ \\ 1,2,3 Marine Science, East Kutai Agricultural College School (STIPER), Jl. Soekarno Hatta,Tlk. Lingga, \\ Sangatta, Kabupaten Kutai Timur, Kalimantan Timur 75683, Indonesia. \\ Email: rosdi_anto@yahoo.com
}

*Corresponding Author, Received: March 10, 2021. Revised: May 11, 2021. Accepted: May 26, 2021

\begin{abstract}
Research aims to determine the value of concentration and spread profile of chlorophyll-a in Birah-birahan Island waters. To process the spread profile data of chlorophyll-a concentration in Birah-Birahan Island waters, the data were used is Landsat 8 imagery data in 2018, i.e. February and August and February and October in 2019, data processing uses the er-mapper and arcgis application by using the Pentury algorithm and Hanintyo algorithm. Information was obtained that the value of chlorophyll-a concentration used the pentury algorithm in 2018, February on west monsoon, i.e. $0.06 \mathrm{mg} / \mathrm{m}^{3}$ and August on east monsoon, i.e. 0.07 $\mathrm{mg} / \mathrm{m}^{3}$, in 2019 February on west monsoon, namely $0.06 \mathrm{mg} / \mathrm{m}^{3}$ and October on east monsoon is $0.07 \mathrm{mg} / \mathrm{m}^{3}$ and chlorophyll-a concentration value using the Hanintyo algorithm in 2018 February on west monsoon i.e. $0.22 \mathrm{mg} / \mathrm{m}^{3}$ and August in the east monsoon is $0.27 \mathrm{mg} / \mathrm{m}^{3}$, in 2019 February on west monsoon i.e. $0.25 \mathrm{mg} / \mathrm{m}^{3}$ and October on east monsoon i.e. $0.24 \mathrm{mg} / \mathrm{m}^{3}$. It can be concluded that the concentration value by the pentury and Hanintyo algorithm of two different years in west and east monsoon the highest chlorophyll-a concentration value were known based on Hanintyo algorithm.
\end{abstract}

Keywords: Chlorophyll-a, Landsat 8, Spread, Birah-Birahan Island

This work is licensed under the Creative Commons Attribution-Share Alike 4.0

International License

\section{INTRODUCTION}

One of the indicators to determine the fertility of waters is by detecting primary production in these waters. High primary productivity is indicated by the spread of high chlorophyll-a concentrations as well. Chlorophyll-a comes from photosynthetic process which is conducted by phytoplankton with sunlight support [17].

Phytoplankton which performs photosynthesis will be a source of food for zooplankton, then will be eaten by small fish, and small fish will be eaten by larger fish to form a food chain in waters. So from food chain process we can predict the area where fish are present so that it will facilitate fishing activities. In 2 DPI determination, so far fishermen are still using the traditional method, i.e. by intuition and experience. These method is still uneffective and efficient, so the level of certainty of catch is still minimal [18].

Based on these factors, an efforts are needed to monitor the spreading of chlorophyll-a in Birahbirahan Island, considering its importance of water potential that supports various needs. One of the monitoring that can be done is using remote sensing satellite data. Utilization of remote sensing satellite data has several advantages, including: wide area coverage, high repeatability, and ease in spatial analysis. The concentration and spreading patterns of chlorophyll-a it can be observed using Landsat 8 OLI satellite imagery by entering an algorithm to compare the field values and values using satellite imagery.

Birah-Birahan Island is a small island with an area about 15 hectares, located in Manubar Village, Sandaran District, East Kutai Regency. Research on mapping the spreading of chlorophyll-a in Birahbirahan Island waters is considered important to be conducted to obtain scientific information regarding the spreading of chlorophyll-a concentration values.

\section{METHOD}

The research method used was a descriptive. Descriptive method is a research method that aims to provide a systematic and factual description of facts [8]. Chlorophyll-a data is obtained from Landsat 8 satellite imagery data by location determination of pet/row 116/59 it taken for 2 years, from 2018-2019. Imagery data is obtained from downloaded data by the USGS page with the address http://earthexplorer.usgs.gov, data in 2018 
is February and August and data in 2019 on February and October to represent west and east monsoons. The extracted area or scale were used for chlorophyll-a analyzing data on research map i.e. $1: 15,000$ and observation area i.e. 785 hectares $/ 7,850,069 \mathrm{~m}^{2}$.

The data were analyzed descriptively and comparatively, i.e. by seeing, describing and comparing the color degradation in the image to describe the spreading of chlorophyll-a concentrations spatially and temporally, and analyzed by Hanintyo algorithm and Pentury algorithm data.

Radiometric correction was conducted to correct errors or distortions which is caused by imperfect operations and sensors, electromagnetic attenuation waves by atmosphere, variations in data retrieval angles, variations of elimination angles, reflection angles and others that can be occur in data retrieval, transmission and recording. The main purpose of radiometric calibration was to convert the digital number values into radians, reflectants and brightness temperature values for thermal infrared channel [25].

Radiometric calibration it can be done manually using parameters stored in metadata from Landsat 8 or automatically using software. DN transformation values into ToA reflectants it can be seen by the following equation.

$$
\rho \lambda^{\prime}=\left(\left(M p^{*} Q c a l\right)-A p\right) / \cos \theta
$$

Where:

$\rho \lambda{ }^{\prime}=$ ToA reflectance, without correction for solar angle

$\mathrm{M} \rho=$ Reflectance_Mult_Band_x, where $\mathrm{x}$ is the band number

$\mathrm{A} \rho=$ Reflectance_Add_Band_x, where $\mathrm{x}$ is the band number

Qcal $=$ Digital Number Value $(D N)$

\section{Algorithm Formulas}

a. Hanintyo's Algorithm

Hanintyo (2014), conducted research on chlorophyll-a in Bali strait by developing an algorithm for estimating chlorophyll-a using Landsat 8-OLI imagery. Hanintyo's algorithm can be seen in equation 1 .

Chl-a:0.2818*(pow(B2/B3 , 3.497) $)$

Where:

Chl-a: Chlorophyll-a

B2: Landsat 8 OLI + Channel 1 (Blue Band)

B3: Landsat 8 OLI + Channel 2 (Green Band)

\section{b. Pentury Algorithm}

The extraction of chlorophyll-a concentration value uses an algorithm developed by [20], which is adjusted to chlorophyll-a concentration value in situ and uses Landsat 8 reflectance value of research area so that the Pentury Algorithm it can be seen in equation 2 .

$$
\text { Chl- } a=0,067(\mathrm{~B} 2 / \mathrm{B} 1)+0,126
$$

Where:

Chl - a: Chlorophyll-a

B2: Landsat 8 OLI + Channel 1 (Blue Band)

B3: Landsat 8 OLI + Channel 2 (Green Band)

\section{RESULTS AND DISCUSSION}

a. General Conditions of Research Location

Birah-Birahan Island is located in Sandaran District, East Kutai Regency, East Kalimantan Province. Birah-Birahan Island has an island 15 hectares area. Even though the location is far from the city, Birah-birahan Islandwaters area, in Sandaran district, East Kutai Regency is fairly beautiful and chic. The condition of the place is still isolated and transportation to get there requires extra struggle. When viewed closely, the location of the coast and its underwater ecosystem is not inferior to the tourist attractions on Derawan Island in Berau Regency. The existing coral reefs still look clean and neat, so they are worthy of being a tourist destination. In Birah-birahan Island, there are many mangroves that surrounded the island, and also as a place for turtles to lay eggs because so many of them live on Birah-Birahan Island.

The characteristics of water mass and its mixtures can be affected by winds and the current flow of sea water to Birah-birahan island. Seawater mass was formed from the composition of temperature, salinity, and density at a certain depth. Water temperature of Birah-birahan Island ranges from $28^{\circ} \mathrm{C}-32^{\circ} \mathrm{C}$, and salinity ranges from $32-35$ ppt. Presently condition of Birah-birahan Island is in a state of emergency, due to naughty fishermen are still bombing to fishing in large numbers near the island area. Not only that, this place is the only island in East Kutai as a habitat for hawksbill and green turtles whose numbers have decreased.

\section{B. Chlorophyll-a Concentration in Birah- birahan Island Waters \\ Chlorophyll-a Concentration Based Pentury Algorithm}

Average value of chlorophyll-a concentration pentury algorithm in Birah-birahan Island waters can be seen in Figure 1.

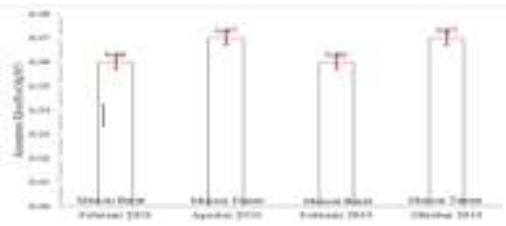

Figure 1. Average value of chlorophyll-a concentration pentury algorithm in Birah-birahan Island waters for 2 years 
Temporally spreading of chlorophyll-a concentration in Birah-birahan Island waters can be seen that the highest value of chlorophyll-a concentration during 2018-2019 occurred on August 2018 and October 2019 using pentury algorithm $0.07 \mathrm{mg} / \mathrm{m}^{3}$ and the lowest value occurred in February 2018 and 2019 with a monthly average value $0.06 \mathrm{mg} / \mathrm{m}^{3}$.

Chlorophyll-a concentration value in BirahBirahan Island waters the pentury algorithm that occurred in West Monsoon (Figure 3) the highest value in August 2018 i.e. $0.07 \mathrm{mg} / \mathrm{m}^{3}$, and the lowest value occurred in October 2019 i.e. 0.07 $\mathrm{mg} / \mathrm{m}^{3}$.

Chlorophyll-a concentration in East monsoon tends to be high even though in October 2019 it decreased. This is presumably due to unstable weather, summer which is still influenced by rainy season. Supported research by [18] the increased chlorophyll-a concentration value in August due to this month being the beginning of entering the East Monsoon, so that the sunlight intensity level starts to heat evenly. This has a positive impact on waters fertility, where the phytoplankton can performed the photosynthesis process optimally. Fluctuations in July and August according to [29], due to unstable weather conditions, changes and strength of wind blowing over the waters resulting dynamics change in these waters.

Fluctuations in chlorophyll-a concentration and spreading in waters are closely related to seasons, oceanographic conditions and natural phenomena that occurred. [4] natural phenomena that affected the oceanographic conditions of Birah-birahan Island are El Nino and La Nina which are the phases of El Nino Southerm Oscillation (ENSO) and Indian Ocean Dipole Mode (IODM) and the process of increasing water mass (Upwelling). In addition, the ENSO phenomenon has an irregular cycle with 2 to 7 period.

There were several increases in chlorophyll-a concentration, i.e. in August 2018 and October 2019, one of which can be presumed as an Upwelling experiencing. In January that is likely to experience Upwelling. [4] Climate Anomaly occurred in 1994 (positive strong IOD in a moderate El-Nino phase) 1997 (strong positive IOD in a strong El-Nino phase) and 2006 (strong positive IOD in a weak El-Nino phase) ) there is a water mass from upwelling on central and southern straits with high intensity.

\section{Chlorophyll-a Concentration Based Hanintyo Algorithm}

Average value of chlorophyll-a concentration Hanintyo algorithm in Birah-birahan Island waters can be seen in Figure 2.

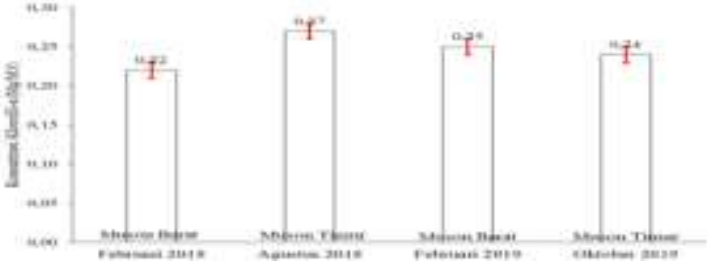

Figure 2. Average value of chlorophyll-a concentration hanintyo algorithm in Birah-birahan Island waters for 2 years

Chlorophyll-a concentration value in Birahbirahan Island waters the hanintyo algorithm that occurred in West Monsoon the highest value in February 2019 i.e. $0.25 \mathrm{mg} / \mathrm{m}^{3}$, and the lowest value occurred in February 2018 using the pentury algorithm $0.22 \mathrm{mg} / \mathrm{m}^{3}$. The change of chlorophyll-a value in this season presumably due to West Monsoon is a rainy season.

Birah-birahan Island waters and its surroundings are influenced by the West and East Monsoons. In West Monsoon period up to the beginning of transitional season, the wind blows from northwest (December-March). November and April (transition season), where the West and East Monsoon influence are still present, causing the opposite movement of wind patterns in Indian Ocean area, so that there is a deflection towards Birah-Birahan Island and the Java Sea with a higher wind speed in Indian Ocean region than in Java Sea, thus affecting Birah-Birahan Island waters [1].

It can be seen from Figures 4 and 9 on February 2018 it can be predicted that ENSO occurred which also coincided with IODM, because DecemberFebruary is the rainy season, but in January there is a quite high increase of chlorophyll-a value and redecline in February. Supported by Amri and Satria's research (2013), upwelling occurred marked by a strong positive IOD in strong El Nino phase, occurring in central and southern straits with high intensity. In this phase, the water mass temperature becomes much lower than normal conditions. In its development there is also a phase opposite to $\mathrm{El}$ Niño, i.e. La Niña. at the time La Niña, the rainfall in most parts of Indonesia increases. This increase in rainfall is highly dependent on intensity of $\mathrm{La}$ Niña [22].

Strong El Niño and La Niña occurrence in $1997 / 1998$ which also coincided with the occurrence of Indian Ocean Dipole it was associate with higher chlorophyll-a concentration values in the upwelling area [26].

Eddies in south strait strengthen around March and April. Strong of water mass entering the East Season also strengthens the eddies that form at thermocline depth, which shows current strength and maximum width in July-September, but it weakeness during the West Season until the 
beginning of transitional season 1 . The annual cycle of Arlindo shows that there is a relationship between the eddies that formed in southern of Libani Canal on the west side and the strength of a flowing stream into Lombok Strait, especially those through the west side. By the time, the eddies on the west side strengthens, the flowing that passing through the west side gets weaker, and otherwise when the eddies weakenes the flowing passing through the west side strengthens. This depends on strength of Arlindo which presumably collided with Dewakang sill, so resulting of currents recirculation that formed eddies. The modeling results show that the circulation of eddies from the Arlindo Makassar jet on East Season can affect the upwelling intensity that occurs in southwestern part the offshore of Makassar coast, so it affecting the spreading area of water mass with low sea surface temperatures and high chlorophyll-a during the upwelling period [15].

The Makassar Strait plays an important role due to it is the main gate through Arlindo passes. Generally, Makassar Strait is a low latitudes passages track that transfers heat, low salinity from Pacific Ocean to Indian Ocean. Arlindo Makassar's meridional flows weakened in an El Nino year. This result is in line with previous research, where El Nino played a role in reducing the Arlindo Makassar's contribution, while in La Nina year, Arlindo Makassar's flowing experienced a strengthening [25].

Chlorophyll-a concentrations in Birah-Birahan Island waters during the West Monsoon (February) spatially. The highest chlorophyll-a concentration value is due to water input from the river. [22] states that the high spreading of chlorophyll-a concentrations in coast waters and the coastal its due to a large supply of nutrients through run-off from land, while the low chlorophyll concentration in offshore waters its due to absence of direct nutrient supply from land.

Chlorophyll-a concentration value in Birahbirahan Island waters the hanintyo algorithm that occurred in West Monsoon the highest value in August 2018 i.e. $0.27 \mathrm{mg} / \mathrm{m}^{3}$, and the lowest value occurred in October 2019 i.e. $0.24 \mathrm{mg} / \mathrm{m}^{3}$.

Chlorophyll-a concentration spatially that occurred in August was the location of higher chlorophyll-a concentration spreading. The rise of deep water to the surface layer in southern Makassar Strait waters it is not only caused by the impact of Indonesian cross-currents circulation , but there is a strong role for southeastern trade winds and and Indian Ocean dipole models influence [26]. High water productivity were identified by the high chlorophyll-a concentration in these waters.

Chlorophyll-a concentration is one of the most parameters that determine primary productivity in the ocean. High and low spreading of chlorophyll concentrations are closely related to the conditions of oceanographic waters. Spreading of chlorophylla concentrations is generally high in coastal waters as a result of high nutrient supply from land through river water runoff, and low in offshore waters. However, high chlorophyll-a concentrations can also be found in offshore waters due to caused by water mass circulation process [27].

Spreading of chlorophyll-a concentrations is higher in coastal waters than in high seas due to high supply of nutrients from land. Water quality monitoring is conventionally limited spatially and temporally. Remote sensing techniques can be used to monitor water quality both spatially and temporally. Satellite imagery analysis can also identify eutrophication using multitemporal observation through remote sensing [13].

Satellite imagery analysis it shows that around the coast waters are higher than the waters that are away from land or around the offshore. One of caused the primary productivity heigh around the land due to in coastal waters there are important ecosystems such as coral, seagrass and mangrove ecosystems that supply nutrients. Chlorophyll-a concentration spreading spatially maps in coastal satellite imagery which has shallow water depth that receives sunlight and a number of nutrients from land [5]. In addition, the water mass exchange with the Pacific Ocean through Sulawesi Sea, Flores Sea and Java Sea affects the level of primary productivity in southern waters of Makassar Strait [14].

\section{CONCLUSION}

Based on pentury algorithm, chlorophyll-a concentration value in west and east monsoons, the west monsoons represented by February 2018 and February 2019 as much as $0.06 \mathrm{mg} / \mathrm{m}^{3}$, the east monsoons represented by August 2018 and October 2019 as much as $0.06 \mathrm{mg} / \mathrm{m}^{3}$ it means that two years of observation have the same chlorophyll-a concentration value. Based on Hanintyo algorithm chlorophyll-a concentration value in west and east monsoons, the west monsoons are represented by February 2018, i.e. $0.22 \mathrm{mg} / \mathrm{m}^{3}$ and February 2019 as much as $0.25 \mathrm{mg} / \mathrm{m}^{3}$, the east monsoon is represented by August 2018 i.e. $0.27 \mathrm{mg} / \mathrm{m}^{3}$ and October 2019 was $0.24 \mathrm{mg} / \mathrm{m}^{3}$.

\section{REFERENCES}

[1] Aeni, N. Analisis Suhu Permukaan Laut dan Klorofil-a dari Citra Aqua Modis Serta Hubungannya Dengan Hasil Tangkapan Ikan Pelagis di Selat Sunda [SKRIPSI]. Bogor: Fakultas Perikanan dan Ilmu Kelautan, Institut Pertanian Bogor. 2012

[2] Aftriana, CV. Analisis Perubahan Kerapatan 
Vegetasi Kota Semarang Menggunakan Bantuan Teknologi Penginderaan Jauh [SKRIPSI]. Semarang: Fakultas Geografi, Universitas Negeri Semarang. 126 hlm. 2013

[3] Aini, MQ. Kajian Distribusi Fitoplankton di Sebagian Laut Utara Jawa Menggunakan Citra MODIS [SKRIPSI]. Yogyakarta: Fakultas Geografi, Universitas Gajah Mada. 2007

[4] Amri, K, dan Satria, F. Impact of Climate Anomaly on Catch Composition of Neritic Tuna In Sunda Strait. Indonesian Fisheries Research Journal. 19(2): 1-17. 2013

[5] Asriyana, Yuliana. Produktivitas Perairan. Bumi Aksara. Jakarta. 2012

[6] Atmadipoera, A.R, Molcard, G., et. al. Characteristics and variability of the Indonesian throughflow water at the outflow straits. Deep-Sea Res. I., 56: 1942-1954. 2009

[7] Fitriah, N. Aplikasi Data Inderaan Multi Spektral untuk Estimasi Kondisi Perairan dan Hubungannya dengan Hasil Tangkapan Ikan Pelagis di Selatan Jawa Barat [SKRIPSI]. Bogor: Fakultas Perikanan dan Ilmu Kelautan Institut Perairan Bogor. 2008

[8] Hamuna, B, Paulangan, Y.P., et. al. Kajian suhu permukaan laut menggunakan data satelit Aqua MODIS di perairan Jayapura Papua. Jurnal Perikanan dan Ilmu Kelautan. 4(3): 160 $-167.2015$

[9] Hendiarti, N, Suwarso., et. al. Seasonal Variation of Pelagic Fish Catch Around Java. Oceanography 18(4): 112-123. 2005

[10] Indrastomo, D.F, Sukadana, I.G., et. al. Interpretasi Vulkanostratigrafi Daerah Mamuju Berdasarkan Analisis Citra landsat 8 . Eksplorium. 36.(2). 2017

[11] Kunarso, Hadi, S, Ningsih., et. al. Variabilitas Suhu dan Klorofil-a di Daerah Upwelling pada Variasi Kejadian ENSO dan IOD di Perairan Selatan Jawa sampai Timor. Ilmu Kelautan, 16 (3): 171-180. 2011

[12] Lillesand, T.M dan R.W, Kiefer. Penginderaan Jauh dan Interpretasi Citra Digital. Yogyakarta: Gadjah Mada University Press. 1990

[13] Moses, W.J, Gitelson, A.A., et. al. Satellite estimation of chlorophyll-a concentration using the red and nir bands of Meris - the Azov sea case study. IEEE Geoscience and Remote Sensing Letter. Vol. 6, No.4. 2009

[14]Muripto, I. Analisis Pengaruh Faktor Oseanografi terhadap Sebaran Spasial dan Temporal Sumberdaya Ikan di Selat Sunda. [TESIS]. Bogor: Sekolah Pascasarjana Institut Pertanian Bogor. 2000
[15] Nababan, B.N, Rosyadi, D., et. al. The seasonal variability of sea surface temperature and chlorophyll-a concentration in the southern Makassar Strait. Procedia Environmental Sciences, 330(2016):583-599. 2016

[16] Nontji, A. Laut Nusantara. Djambatan. Jakarta. 690 hlm. 2005

[17] Nuriya, HZ, Nugraha, W.A., et. al. Pengukuran Konsentrasi Klorofil-a dengan Pengolahan Citra Landsat ETM-7 dan Uji Laboratorium di Perairan Selat Madura Bagian Barat. Jurnal Kelautan. 3(1). 60-66. 2010

[18] Nuryahya, R.A. Sebaran Konsentrasi Klorofila di Perairan Pulau Jawa Bagian Barat Dan Lampung Berdasarkan Data Citra Satelit Terra Modis. Serang: Fakultas Pertanian Universitas Sultan Ageng Tirtayasa. 2018

[19] Nuzapril, M. Sebaran Konsentrasi Klorofil-a dan Produktivitas Primer di Perairan Karimunjawa Menggunakan Citra Satelit Landsat 8. Bogor: Sekolah Pascasarjana Institut Pertanian Bogor. 2017

[20] Pentury, R. Algoritma pendugaan konsentrasi klorofil-a di Teluk Ambon dengan Menggunakan Citra Landsat [TESIS]. Bogor: Institut Pertanian Bogor. 1997

[21] Prianto, Ulqodry T.Z., et. al. Pola Sebaran Konsentrasi Klorofil-a di Selat Bangka dengan Menggunakan Citra Aqua-Modis. Jurnal Maspari (1):22-33. 2003

[22] Ramansyah, F. Penentuan Pola Sebaran Konsetrasi Klorofil-a di Selat Sunda dan Perairan Sekitarnya Dengan Menggunakan Data Inderaan Aqua Modis. Bogor: Fakultas Perikanan dan Ilmu Kelautan. Institut Pertanian Bogor. 2009

[23] Sinaga, M.P. Analisis Hasil Tangkapan Pukat Ikan Kaitannya dengan Kandungan Klorofil-A dan Suhu Permukaan Laut di Perairan Tapanuli Tengah. Bogor: Sekolah Pascasarjana Institut Pertanian Bogor. 2009

[24] Sitanggang, G. Kajian Pemanfaatan Satelit Masa Depan: Sistem Penginderaan Jauh Satelit LCDM (Lansat-8). Berita Dirgantara.11(2):47- 58. 2010

[25] Sprintall, J, Gordon, R., et. al. A semiannual Indian Ocean forced Kelvin wave observed in the Indonesian seas in May 1997. J. Geophys. Res., 105 (C7):17.217-17.230. 2000

[26] Susanto, R.D and Marra, J. Effect of the 1997/98 El Nino on Chlorophyll-a VariabilityAlong the Southern Coasts of Java and Sumatera. Oceanography. 18 (4):124-127. 2005 
[27] Syahdan, M, Susilo, S.B., et. al. Variability of surface chlorophyll-a in the Makassar Strait Java Sea, Indonesia. IJSBAR., 14(2):103-116.

[28] Wyrtki, K. 1961. Physical Oceanography of the Southeast Asian Waters. Naga Report. (2). 2014

[29]Zulkarnaen, D. Variabilitas Konsentrasi Klorofil-a dari Citra Satelit SeaWiFS di Perairan Pulau Moyo, Kabupaten Sumbawa, Nusa Tenggara Barat. Bogor: Fakultas Perikanan dan Ilmu Kelautan, Institut Perairan Bogor. 2009 